\title{
Age, noise and cGMP: Pharmacological activation of soluble guanylyl cyclase (sGC) interacts with the progression of age related and noise induced hearing loss
}

\author{
Lukas Rüttiger $^{1 *}$, Ksenia Varakina ${ }^{1}$, Dorit Möhrle ${ }^{1}$, Dan Bing ${ }^{1}$, Peter Sandner ${ }^{2,3}$, Marlies Knipper ${ }^{1}$ \\ From 7th International Conference on cGMP Generators, Effectors and Therapeutic Implications \\ Trier, Germany. 19-21 June 2015
}

\section{Background}

Progressing loss of sensory function is a major problem of aging populations. In humans and animals, loss of auditory function becomes evident by increased hearing thresholds, altered sound processing, and abnormal perception of above-threshold sounds or phantom perceptions like hyperacusis and tinnitus [1,2]. Recent studies could identify the close relation between aging, loss of inner hair cell synaptic contacts, and auditory brainstem responses [3]. In a previous study we reported that pharmacological PDE5 inhibition reduces hair cell damage following auditory noise exposure indicating a protective molecular cascade mediated by cGMP signaling [4]. Candidate components of this protective cascade have been described within the last decades, however, the upstream components involved in the protective cascade (cGMP-generators) in the cochlea are still unknown. We therefore tested the protective potential of cGMP increase by pharmacological stimulation of soluble guanylyl cyclase (sGC) for age and noise induced progression of hearing deficits.

\section{Materials and methods}

Synaptic structures, afferent synaptic contacts, and auditory fibers were studied in an animal model on young (3-9 month old) and aged (20-24 month old) rats. The hearing sensation was monitored by auditory evoked brainstem responses (ABR) and otoacoustic emissions (DPOAE) giving insight for the central and peripheral

\footnotetext{
* Correspondence: lukas.ruettiger@uni-tuebingen.de

'Department of Otolaryngology, Eberhard-Karls-Universität Tübingen, Germany

Full list of author information is available at the end of the article
}

(hair cell function) auditory capacity, respectively. Hyperacusis and tinnitus sensation in the rat were tested using a behavioral approach [5]. We pharmacologically stimulated cGMP production by an sGC-stimulating drug administered in the food for 25 days or several months. To estimate for the number of afferent contacts CtBP2/RIBEYE immuno-positive staining at the IHC synapse was quantified.

\section{Results}

Auditory thresholds were increased and the auditory response range was reduced over age. The characteristic changes over age were similar to the changes observed after exposure to traumatizing sound. sGC treatment interacts with the loss of age related and auditory trauma induced loss of hair cell synaptic ribbons in a complex way, proposing that a subclass of auditory fibers with a special vulnerability can be rescued by sGC treatment within a defined time window.

\section{Conclusion}

Age related and noise induced decline of hearing function are correlated with auditory responses and morphological specifications of hair cell molecular phenotype. The data need to be discussed regarding the proposed cGMP generators in the inner ear and their role for an otoprotective molecular cascade after noise induced damage of the ear or progression of presbycusia.

\section{Acknowledgements}

This work was supported by grants from the Deutsche

Forschungsgemeinschaft (FOR 2060 project FE 438/5-1) and Action on Hearing Loss (RNID G54-Ru). 


\section{Authors' details}

${ }^{1}$ Department of Otolaryngology, Eberhard-Karls-Universität Tübingen, Germany. ${ }^{2}$ Bayer Health Care, Global Drug Discovery-Common Mechanism Research, Wuppertal, Germany. ${ }^{3}$ Hannover Medical School, Institute of Pharmacology, Hannover, Germany.

Published: 2 September 2015

\section{References}

1. Knipper M, Van Dijk P, Nunes I, Rüttiger L, Zimmermann U: Advances in the neurobiology of hearing disorders: Recent developments regarding the basis of tinnitus and hyperacusis. Prog Neurobiol 2013, 111:17-33.

2. Singer W, Zuccotti A, Jaumann M, Lee SC, Panford-Walsh $R$, Xiong $H$, et al: Noise-induced inner hair cell ribbon loss disturbs central arc mobilization: a novel molecular paradigm for understanding tinnitus. Mol Neurobiol 2013, 47(1):261-279.

3. Sergejenko Y, Lall K, Liberman MC, Kujawa SG: Age-related cochlear synaptopathy: an early-onset contributor to auditory functional decline. J Neurosci 2013, 33(34):13686-13694

4. Jaumann M, Dettling J, Gubelt M, Zimmermann U, Gerling A, PaqueDurand $F$, et al: cGMP-Prkg1 signaling and Pde5 inhibition shelter cochlear hair cells and hearing function. Nat Med 2012, 18(2):252-259.

5. Rüttiger $L$, Ciuffani J, Zenner HP, Knipper M: A behavioral paradigm to judge acute sodium salicylate-induced sound experience in rats: a new approach for an animal model on tinnitus. Hearing Research 2003, 180(1-2):39-50.

doi:10.1186/2050-6511-16-S1-A81

Cite this article as: Rüttiger et al:: Age, noise and cGMP:

Pharmacological activation of soluble guanylyl cyclase (sGC) interacts with the progression of age related and noise induced hearing loss. BMC Pharmacology and Toxicology 2015 16(Suppl 1):A81.

\section{Submit your next manuscript to BioMed Central} and take full advantage of:

- Convenient online submission

- Thorough peer review

- No space constraints or color figure charges

- Immediate publication on acceptance

- Inclusion in PubMed, CAS, Scopus and Google Scholar

- Research which is freely available for redistribution

Submit your manuscript at www.biomedcentral.com/submit
Biomed Central 